\title{
Value of DWI volumetry for assessment of complete rectal cancer response after CRT
}

\author{
M Nazar , A Vazquez, L Alarcon, M Pascuzzi, M Wirtz, E Eyheremendy \\ From International Cancer Imaging Society Meeting and 15th Annual Teaching Course (ICIS 2015) \\ London, UK. 5-7 October 2015
}

\section{Learning objectives}

To determine the diagnostic performance of DWI volumetry for the assessment of complete response after CRT in patients with locally advanced rectal cancer and to compare with volumetry on standard T2- weight MRI, by means of volumetric signal intensity measurements.

\section{Content organisation}

We retrospectively analyzed 25 patients with locally advanced rectal cancer. Patients underwent pre and postCRT standard T2 weight MRI and DWI MRI. We placed free-hand regions of interest and each tumour-containing section to determine pre and post-CRT tumour volumes.

Histologic findings were the standard of reference.

\section{Conclusion}

Volumetry of the viable tumour remmants based on signal intensity characteristic on DW images after CRT was shown to be more valuable than volumetry of the tumour based on morphologic T2w images for the differentiation between a pCR and residual tumour in locally advanced rectal cancer.

Submit your next manuscript to BioMed Central and take full advantage of:

- Convenient online submission

- Thorough peer review

- No space constraints or color figure charges

- Immediate publication on acceptance

- Inclusion in PubMed, CAS, Scopus and Google Scholar

- Research which is freely available for redistribution 